\title{
Perancangan Motif Batik Model Fraktal IFS
}

\section{Yang Dapat Didaur Ulang}

\author{
Tedjo Darmanto \\ Program Studi Teknik Informatika \\ STMIK AMIK Bandung \\ Jl. Jakarta 28 Bandung \\ tedjodarmanto@stmik-amikbandung.ac.id
}

\begin{abstract}
Abstrak-Makalah hasil penelitian ini membahas tentang bagaimana melakukan perancangan motif batik apakah jika perancangan tersebut dilakukan melalui model fraktal IFS akan diperoleh proses perancangan yang lebih sederhana. Secara teori setiap obyek pada umumnya dapat digambarkan dengan model fraktal. Model fraktal IFS sebagai salah satu model fraktal secara sederhana dapat dinyatakan dengan kode IFS dan dibangkitkan dengan algoritma Iterasi acak menjadi obyek fraktal yang diwakilinya. Kelebihan perancangan obyek gambar melalui model fraktal IFS dibandingkan dengan model lain adalah dalam hal kemudahan daur ulang melalui proses Reverse engineering.
\end{abstract}

\section{Kata kunci-Motif batik; Model fraktal; Fraktal IFS; Kode IFS; Algoritma Iterasi acak; Reverse engineering}

\section{PENDAhULUAN}

Model fraktal dapat dimanfaatkan untuk memudahkan merancang motif batik baik yang bersifat simetris dalam arah horizontal dan vertikal atau salah satunya atau yang bersifat tidak simetris. Rancangan motif batik simetris sederhana dapat dirancang dengan model fraktal secara sederhana. Paling tidak terdapat dua model fraktal, yaitu model fraktal Sistem-L dan model fraktal IFS (Iterated Function Systems).

Untuk perancangan motif batik, maka model fraktal IFS lebih sesuai karena lebih dapat menggambarkan segala jenis obyek fraktal dibandingkan dengan model fraktal Sistem-L. Fraktal pertamakali diperkenalkan oleh bapak fraktal yaitu Benoit Mandelbrot pada tahun 1982 [1]. Fraktal lebih dipopulerkan melalui model fraktal IFS oleh Michael Barnsley dan Demko pada tahun 1985 [2] melalui model matematis fungsi Affine dan teorema Collage yang memanfaatkan sifat keserupaan diri (self-similarity) yang disampaikan pertamakali oleh Hutchinson [3]. Melalui sifat keserupaan diri fraktal, maka perancangan sebarang obyek alam terutama yang umumnya mempunyai sifat keserupaan diri seperti pohon dan awan lebih dimudahkan. Pada model fraktal IFS proses pengkodean menjadi kode IFS yang berasal dari perancangan Collage dapat dilakukan daur ulang baik melalui penambahan komponen Collage, maupun melalui proses Reverse engineering [5].

\section{MetodE}

\section{A. Fraktal}

Model fraktal merupakan model geometri yang dapat menggambarkan obyek yang mempunyai dimensi dengan bilangan yang tidak bulat. Seperti kita ketahui obyek berdimensi satu adalah garis lurus yang mengarah ke salah satu arah koordinat. Obyek berdimensi dengan bilangan positif lebih kecil dari satu adalah garis lurus putus-putus yang mengarah ke salah satu arah koordinat.

Seperti kita ketahui obyek berdimensi dua salah satunya adalah obyek persegi empat yang di dalamnya tidak ada ruang kosong. Jika pada obyek persegi empat tersebut terdapat ruang-ruang kosong maka dimensinya berkurang menjadi lebih kecil dari dua. Demikian selanjutnya untuk obyek berdimensi antara dua dan tiga, sebagai contoh adalah obyek kubus yang di dalamnya terdapat ruang-ruang kosong.

\section{B. IFS}

Menurut teori IFS, model obyek fraktal IFS dapat direpresentasikan oleh identitas obyek yang sederhana dan dapat dipetakan secara iteratif melalui algoritma Iterasi acak menjadi obyek yang tampak tidak sederhana. Identitas obyek dipresentasikan dalam bentuk kumpulan koefisien Affine yang disebut kode IFS. Untuk setiap komponen obyek diwakili dengan enam koefisien Affine (a sampai f) ditambah dengan nilai probabilitas kerapatan titik-titik 
Volume 01 Nomor 01 Oktober 2017

yang membentuk komponen tersebut relatif terhadap kerapatan titik-titik yang membentuk obyek fraktal, seperti ditampilkan pada persamaan-1. Persamaan-1 memperlihatkan adanya proses iteratif di mana nilai x' dan y' (current) bergantung pada nilai x dan y sebelumnya, Gambar obyek fraktal dapat dibangkitkan dengan melalui proses decode kode IFS tersebut yang bergantung pada pembangkitan bilangan acak sesuai nilai probabilitas masing-masing komponen obyek, sehingga algoritma decode tersebut disebut sebagai algoritma Iterasi acak [4].

$$
w\left[\begin{array}{l}
x^{\prime} \\
y^{\prime}
\end{array}\right]=\left[\begin{array}{ll}
a & b \\
c & d
\end{array}\right] \cdot\left[\begin{array}{l}
x \\
y
\end{array}\right]+\left[\begin{array}{l}
e \\
f
\end{array}\right]
$$

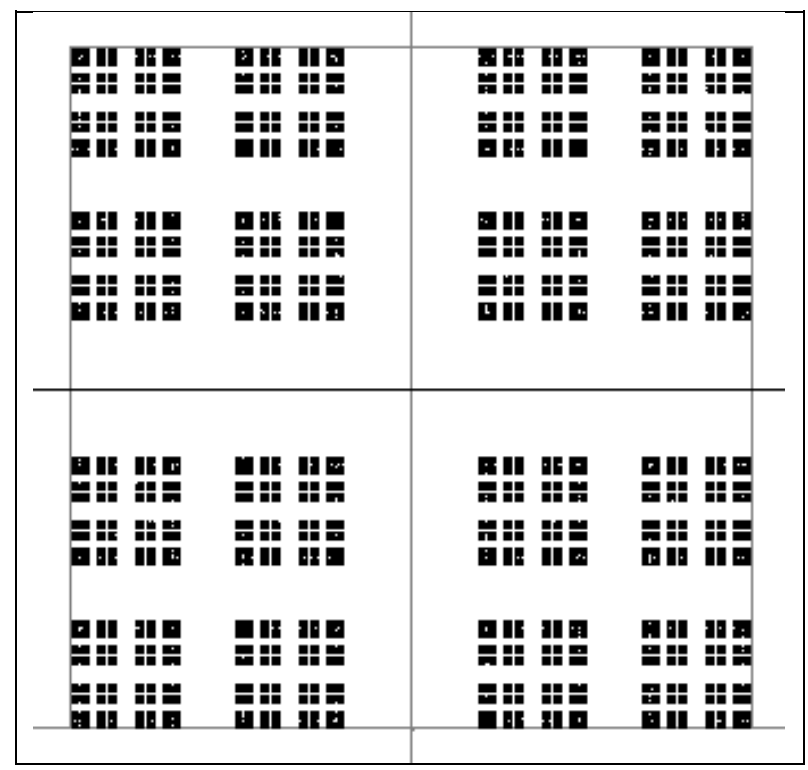

Gambar 1. Obyek fraktal gasket empat komponen

Sebagai ilustrasi pertama, obyek fraktal berdimensi antara satu dan dua dapat dirancang dengan model fraktal IFS yang terdiri dari empat komponen seperti contoh obyek fraktal gasket dengan empat komponen yang ditampilkan pada gambar-1 (di atas). Sebagai ilustrasi kedua, obyek fraktal berdimensi antara satu dan dua dapat dirancang dengan model fraktal IFS yang terdiri dari lima komponen seperti contoh obyek fraktal gasket dengan lima komponen yang ditampilkan pada gambar-2 berikut ini.

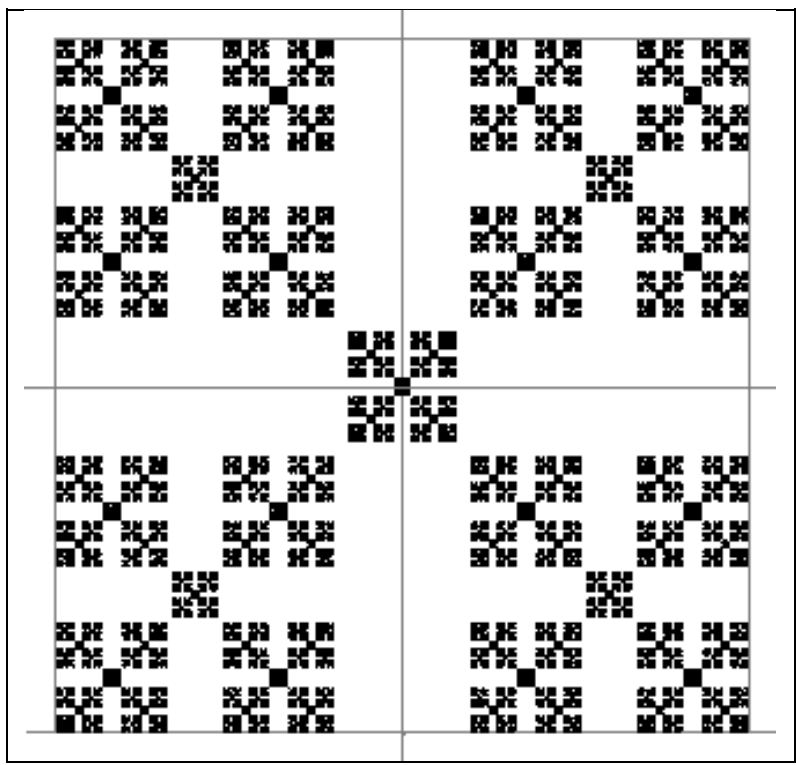

Gambar 2. Obyek fraktal gasket lima komponen 


\section{Model Fraktal IFS}

Model fraktal IFS adalah model fraktal yang menggunakan transformasi pemetaan titik titik pixel untuk menggambarkan obyek fraktal dengan fungsi Affine 2D dan teorema Collage. Fungsi Affine terdiri dari dua bagian, bagian pertama menentukan bentuk dan arah orientasi komponen obyek, sedangkan bagian kedua menentukan skala ukuran komponen relatif terhadap ukuran obyek keseluruhan yang merupakan model matematis. Bagian pertama dinyatakan dalam bentuk matrik yang terdiri dari koefisien $\mathbf{a}, \mathbf{b}, \mathbf{c}$ dan $\mathbf{d}$, sedangkan bagian kedua dinyatakan dengan vektor vertikal yang terdiri dari koefisien e dan f, seperti dinyatakan persamaan-1 yang ditampilkan pada bagian pembahasan IFS di atas.

Model matematis ini disebut juga sebagai fungsi Self-affine karena mempunyai sifat keserupaan diri [5]. Teorema Collage dapat dinyatakan secara visual dan merupakan bentuk visualisasi model matematis tersebut di atas dalam formasi kumpulan komponen Collage. Setiap komponen Collage digambarkan sebagai area segi empat yang dibatasi oleh empat titik dimulai dari titik tertentu sebagai patokan penentuan arah. Setiap area segi empat dapat mempunyai arah yang sama atau berbeda relatif terhadap arah kerangka Collage yang dibatasi empat titik pada pojok kerangka dimulai dari titik kiri bawah berputar searah jarum jam atau kerangka selalu mengarah ke atas. Sebagai ilustrasi model rancangan yang menghasilkan dua obyek fraktal pada gambar-1 dan gambar-2 adalah berdasarkan teorema Collage yang divisualisasikan sebagai dua gambar rancangan Collage pada gambar-3 dan gambar-4.

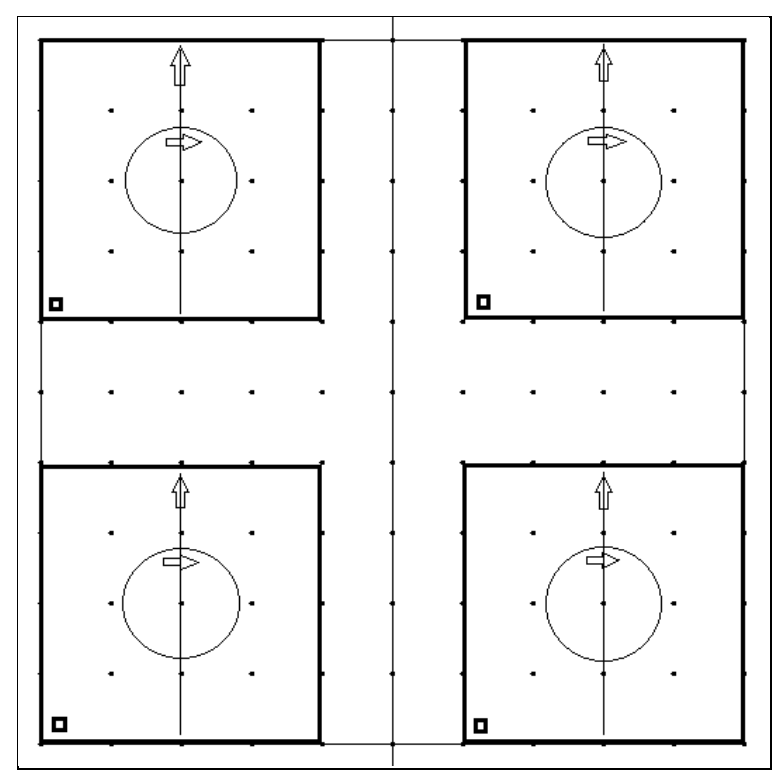

Gambar 3. Model rancangan fraktal gasket empat komponen 


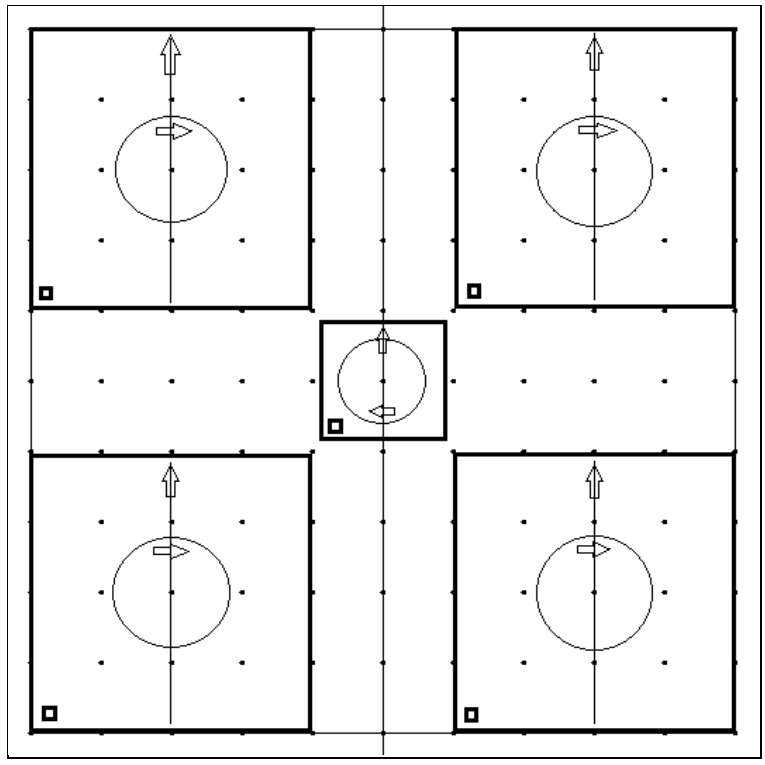

Gambar 4. Model rancangan fraktal gasket lima komponen

\section{PERANCANGAN}

Seperti telah disebutkan sebelumnya kelebihan model fraktal IFS adalah dalam hal kemudahan daur ulang model yang diwakilli oleh kode IFS dan model matematis fungsi Self-affine dan atau model visual teorema Collage [5]. Proses daur ulang dilakukan dengan memanfaatkan proses Reverse engineering melalui perancangan ulang model rancangan komposisi Collage [5], seperti hanya sekedar menggeser beberapa komponen Collage dari posisi semula pada perancangan awal ke posisi baru pada perancangan ulang. Untuk perancangan motif batik dengan model fraktal ini dapat dilakukan dalam beberapa tahap perancangan, mulai dari perancangan awal, lanjut, final dan perancangan ulang.

\section{A. Perancangan Awal}

Pada makalah ini yang merupakan pengembangan dari makalah sebelumnya [6] ditampilkan satu model motif batik (model kelima) yang merupakan daur ulang empat model sebelumnya secara kronologis. Model pertama terdiri dari empat komponen Collage digambarkan dengan komponen-1 sampai 4 pada visualisasi model rancangan pada gambar-5 dan gambar obyek fraktal hasil rancangan ditampilkan pada gambar-6. Model pertama yang terdiri dari empat komponen Collage berbentuk memanjang akan menghasilkan gambar motif garis-garis yang tidak memiliki sifat keserupaan diri.

Model kedua terdiri dari lima komponen Collage digambarkan dengan empat komponen seperti model pertama ditambah satu komponen kelima dari model rancangan pada gambar-5 dan obyek fraktal hasil rancangan ditampilkan pada gambar-7. Pada model kedua ini terdapat satu komponen yang memiliki sifat keserupaan diri, yaitu komponen-5, sehingga menghasilkan gambar motif garis-garis yang serupa dengan tampilan obyek keseluruhan. Komponen-5 ini berada pada bagian pojok kanan bawah kerangka. Pada model kedua komponen kelima mempunyai arah orientasi yang sama seperti kerangka yaitu mengarah ke atas digambarkan dengan area yang dimulai dari titik tengah bawah kerangka ke arah tiga titik lainnya secara searah jarum jam. 


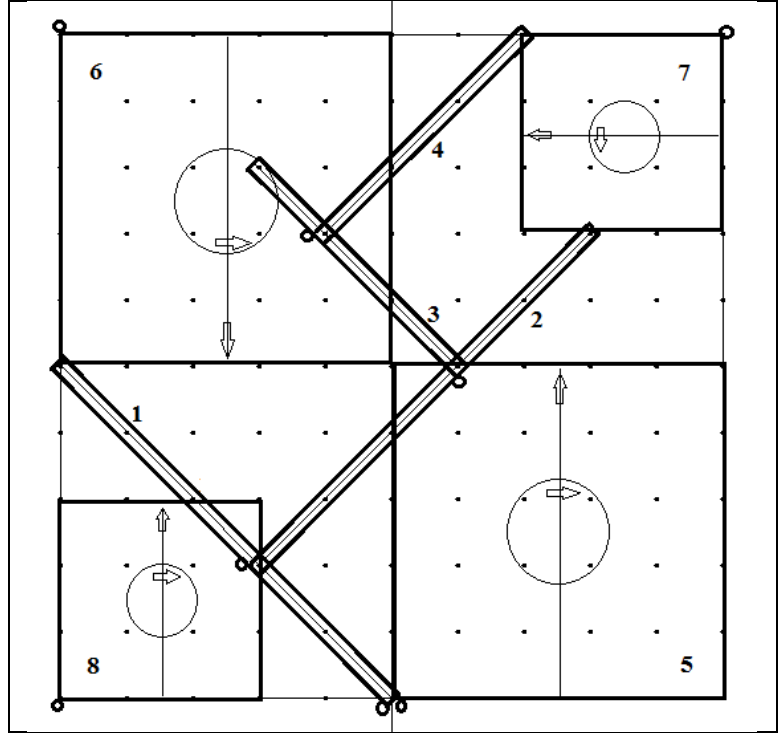

Gambar 5. Contoh model rancangan motif batik (model-1 : komponen-1 s/d 4; model-2: komponen-1 s/d 5; model-3: komponen-1 s.d 6 ; model-4: komponen-1 s/d 7; model-5 komponen-1 s/d 8)

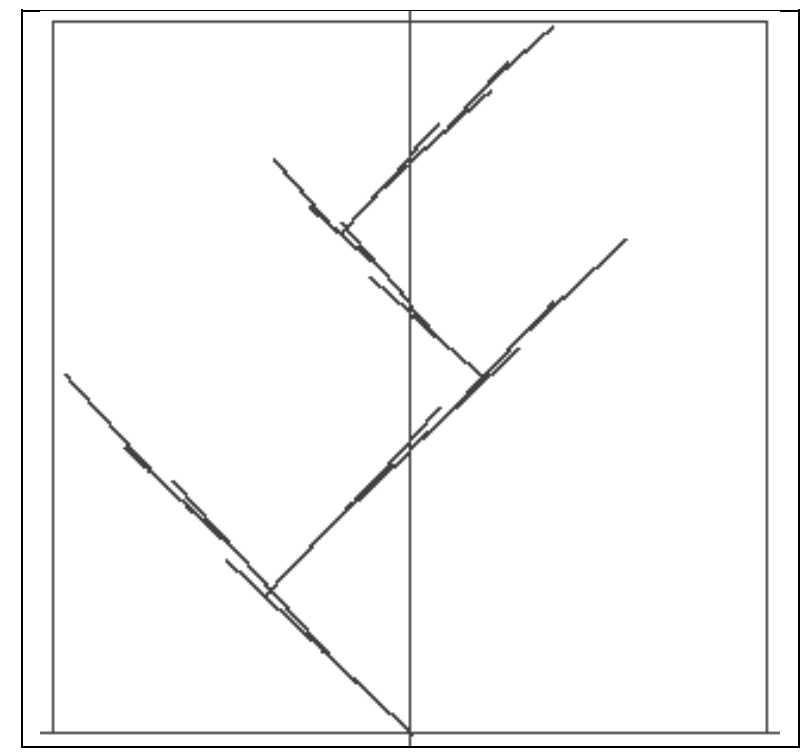

Gambar 6. Obyek fraktal hasil rancangan model-1 (4 komponen) 


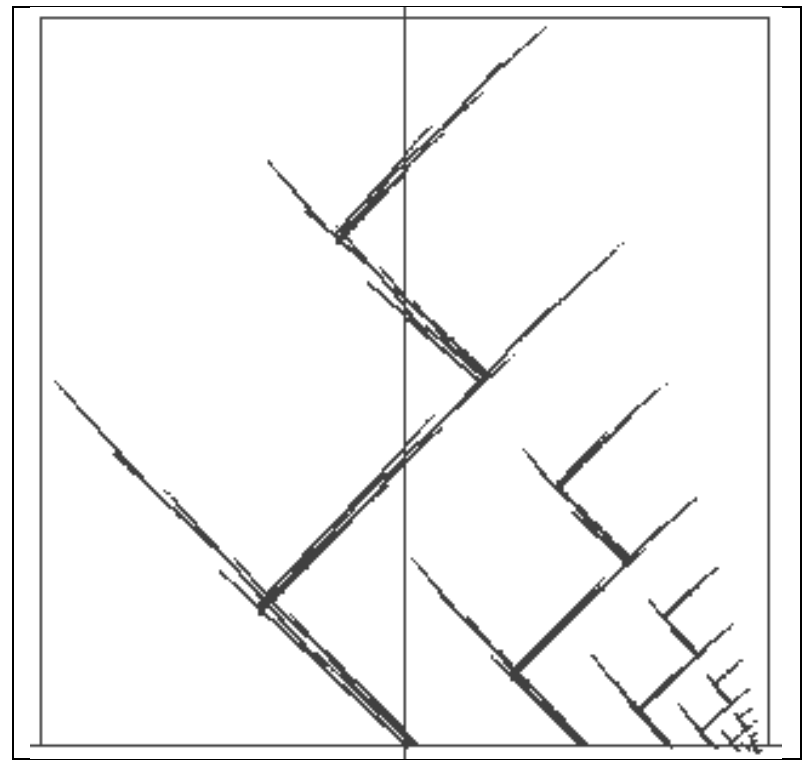

Gambar 7. Obyek fraktal hasil rancangan model-2 (5 komponen)

\section{B. Perancangan Lanjut}

Selanjutnya pada model ketiga sampai kelima, setiap model rancangan ditambah satu komponen yang memiliki sifat keserupaan diri, sehingga pada model ketiga menjadi terdiri dari enam komponen, pada model keempat menjadi terdiri dari tujuh komponen dan pada model kelima menjadi terdiri dari delapan komponen. Pada model ketiga komponen keenam mempunyai arah orientasi ke bawah digambarkan dengan area yang dimulai dari titik pojok kiri atas kerangka ke arah tiga titik lainnya secara berlawanan arah jarum jam. Pada model keempat komponen ketujuh mempunyai arah orientasi ke kanan digambarkan dengan area yang dimulai dari titik pojok kanan atas kerangka ke arah tiga titik lainnya secara berlawanan arah jarum jam. Pada model kelima komponen kedelapan mempunyai arah orientasi ke atas digambarkan dengan area yang dimulai dari titik pojok kiri bawah dari kerangka ke arah tiga titik lainnya secara searah jarum jam.

Komponen keenam model ketiga, komponen ketujuh model keempat dan komponen kedelapan model kelima ditampilkan pada gambar-5 sesuai anotasi. Gambar obyek fraktal hasil rancangan model ketiga sampai kelima ditampilkan pada gambar-8 sampai gambar-10. Kode IFS sebagai identitas obyek fraktal yang belum dinormalisasi ditampilkan pada tabel-1.

TABEL 1. CONTOH KoDE IFS (SEBELUM NORMALISASI)

\begin{tabular}{|c|c|c|c|c|c|c|}
\hline $\mathbf{a}$ & $\mathbf{b}$ & $\mathbf{c}$ & $\mathbf{d}$ & e & f & prob \\
\hline \hline 0.023 & 0.494 & -0.02 & 0.504 & 0.001 & 0.0 & 0,0814 \\
\hline 0.016 & -0.50 & 0.018 & 0.506 & -0.20 & -0.19 & 0,0814 \\
\hline 0.022 & 0.304 & -0.02 & 0.304 & 0.106 & -0.5 & 0,0465 \\
\hline 0.02 & -0.30 & 0.014 & 0.298 & -0.1 & -0.70 & 0,0465 \\
\hline 0.502 & -0.01 & 0.01 & 0.507 & 0.244 & 0.001 & 0,2326 \\
\hline 0.5 & 0.018 & 0.020 & -0.5 & -0.23 & -0.99 & 0,2326 \\
\hline 0.013 & 0.303 & 0.304 & -0.02 & 0.503 & -0.85 & 0,1395 \\
\hline 0.3 & -0.01 & 0.008 & 0.302 & -0.35 & -0.00 & 0,1395 \\
\hline
\end{tabular}

Model pertama diwakili oleh kode IFS baris pertama sampai keempat. Model kedua diwakili oleh kode IFS baris pertama sampai kelima. Model ketiga diwakili oleh kode IFS baris pertama sampai keenam. Model keempat diwakili oleh kode IFS baris pertama sampai ketujuh dan model kelima diwakili oleh kode IFS baris pertama sampai kedelapan (terakhir). 


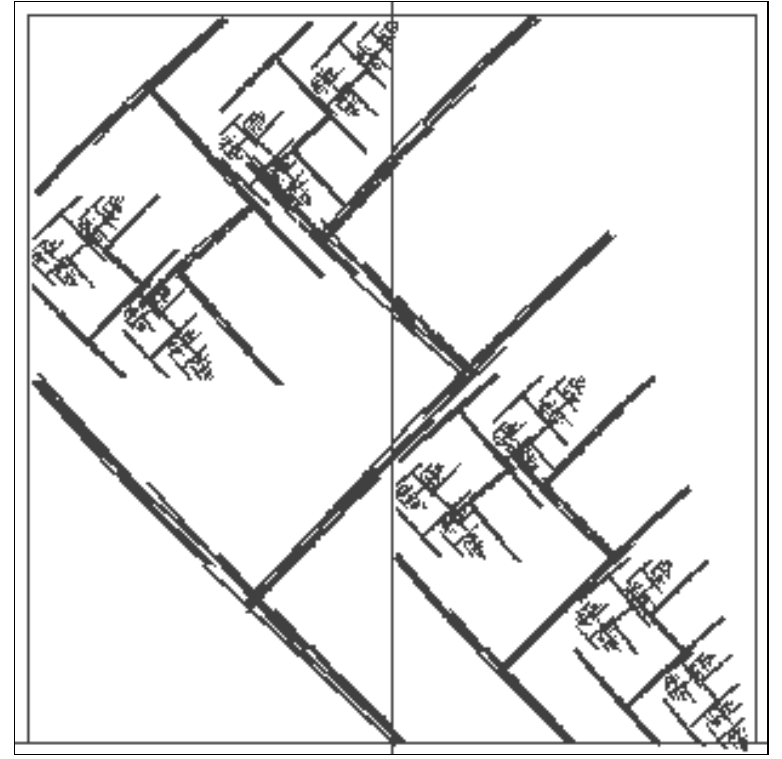

Gambar 8. Obyek fraktal hasil rancangan model-3 (6 komponen)

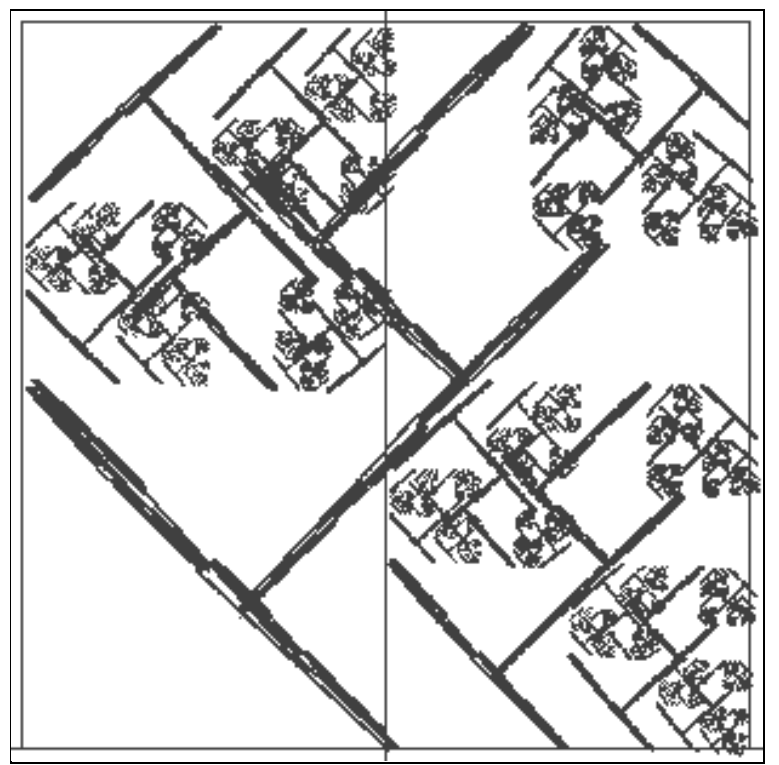

Gambar 9. Obyek fraktal hasil rancangan model-4 (7 komponen) 


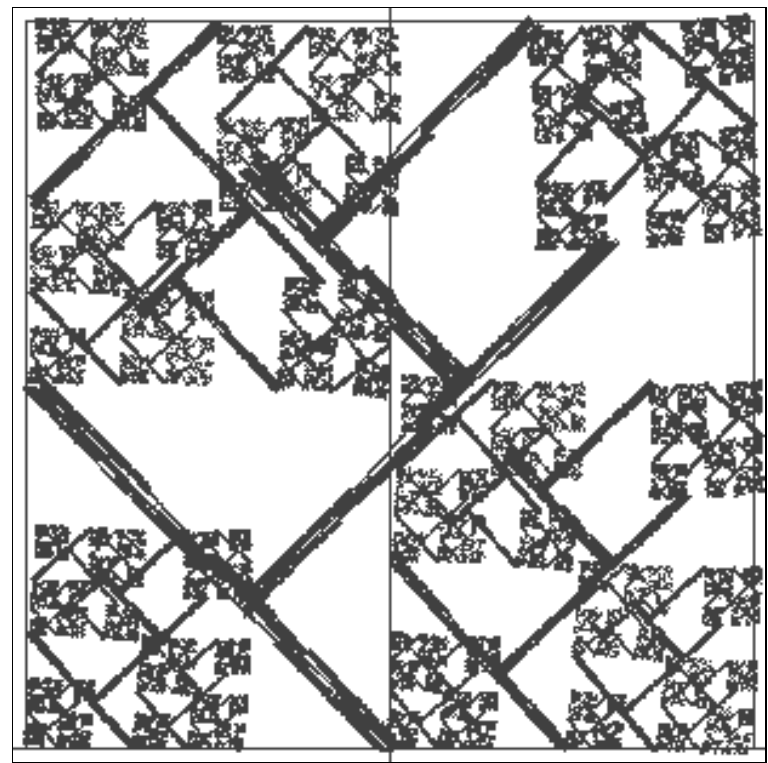

Gambar 10. Obyek fraktal hasil rancangan model-5 (8 komponen)

\section{Perancangan Final}

Pada proses finalisasi rancangan motif batik dilakukan proses pencerminan secara horizontal, vertikal dan kedua-duanya (pencerminan diagonal) dan proses pengubinan (tiling). Sebelum dilakukan proses pencerminan pada kode IFS yang dihasilkan dilakukan normalisasi (tabel-2), yaitu pembulatan nilai koefisien sedemikian sehingga gambar motif yang tidak mempunyai sifat keserupaan diri menjadi berbentuk garis seperti tampak pada gambar-11.

Hasil pencerminan obyek fraktal model kelima pada gambar-11 terhadap sumbu horizontal (sumbu-x) ditampilkan pada gambar-12. Hasil pencerminan obyek fraktal model kelima terhadap sumbu vertikal (sumbu-y) ditampilkan pada gambar-13 dan hasil pencerminan diagonal obyek fraktal model kelima terhadap sumbu horizontal dan vertikal ditampilkan pada gambar-14. Hasil proses pengubinan fase pertama diperoleh motif batik pada gambar-15 yang merupakan hasil pengubinan empat gambar sebelumnya (gambar-11 sampai gambar-14). Hasil proses pengubinan fase kedua diperoleh motif batik pada gambar-16 yang merupakan hasil pengubinan empat obyek fraktal pada gambar-15.

Hasil rancangan final ini yang diwakili rancangan Collage semua komponen (1 sampai 8) pada gambar-5, dapat didaur ulang melalui proses Reverse engineering. Proses Reverse engineering dapat memanfaatkan rancangan yang sudah ada, seperti dengan mengubah posisi komponen Collage tertentu, seperti akan dijelaskan pembahasan pada bagian Perancangan daur ulang.

TABEL 2. CONTOH KODE IFS (SETELAH NORMALISASI)

\begin{tabular}{|c|c|c|c|c|c|c|}
\hline $\mathbf{a}$ & $\mathbf{b}$ & $\mathbf{c}$ & $\mathbf{d}$ & e & f & Prob \\
\hline \hline 0.0 & 0.5 & 0.0 & 0.5 & 0.0 & 0.0 & 0,0814 \\
\hline 0.0 & -0.5 & 0.0 & 0.5 & -0.2 & -0.2 & 0,0814 \\
\hline 0.0 & 0.3 & 0.0 & 0.3 & 0.1 & -0.5 & 0,0465 \\
\hline 0.0 & -0.3 & 0.0 & 0.3 & -0.1 & -0.7 & 0,0465 \\
\hline 0.5 & 0.0 & 0.0 & 0.5 & 0.25 & 0.0 & 0,2326 \\
\hline 0.5 & 0.0 & 0.0 & -0.5 & -0.25 & -1.0 & 0,2326 \\
\hline 0.0 & 0.3 & 0.3 & 0.0 & 0.5 & -0.85 & 0,1395 \\
\hline 0.3 & 0.0 & 0.0 & 0.3 & -0.35 & 0.0 & 0,1395 \\
\hline
\end{tabular}




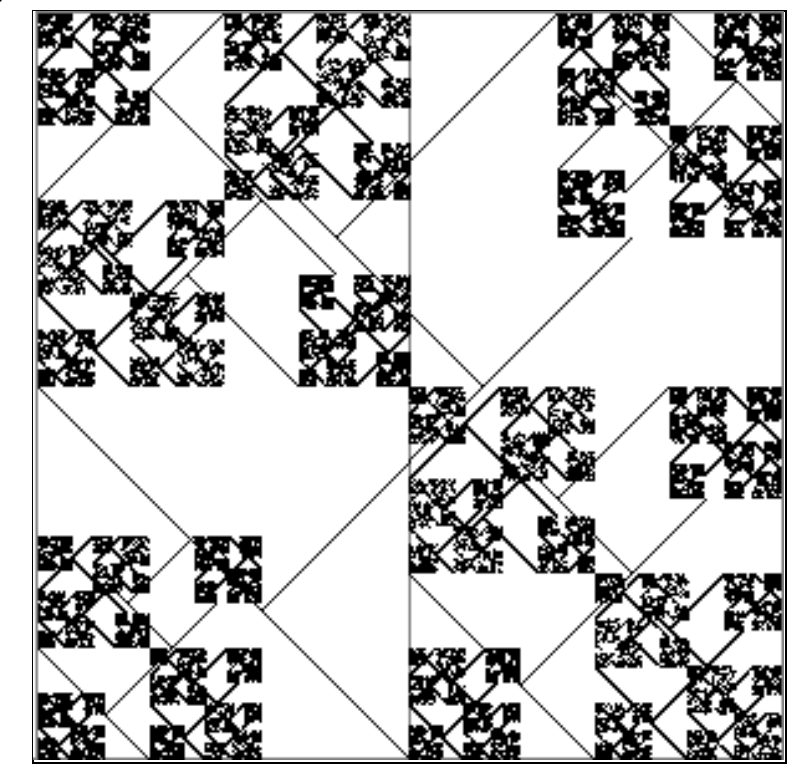

Gambar 11. Obyek fraktal hasil rancangan model-5 (normalisasi)

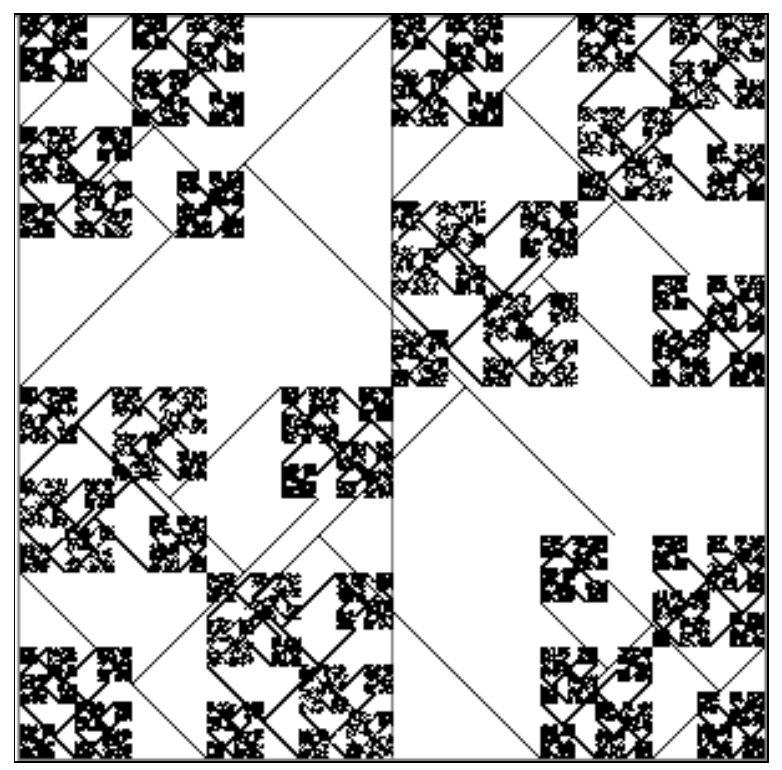

Gambar 12. Obyek fraktal hasil rancangan model-5 (pencerminan vertikal terhadap sumbu-x) 


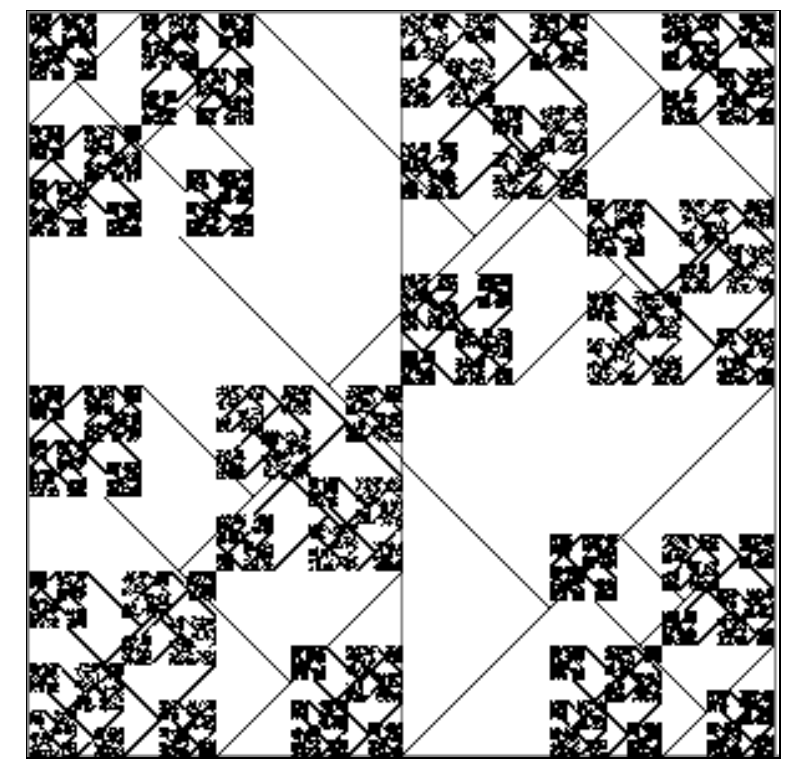

Gambar 13. Obyek fraktal hasil rancangan model-5 (pencerminan horizontal terhadap sumbu-y)



Gambar 14. Obyek fraktal hasil rancangan model-5 (pencerminan diagonal) 


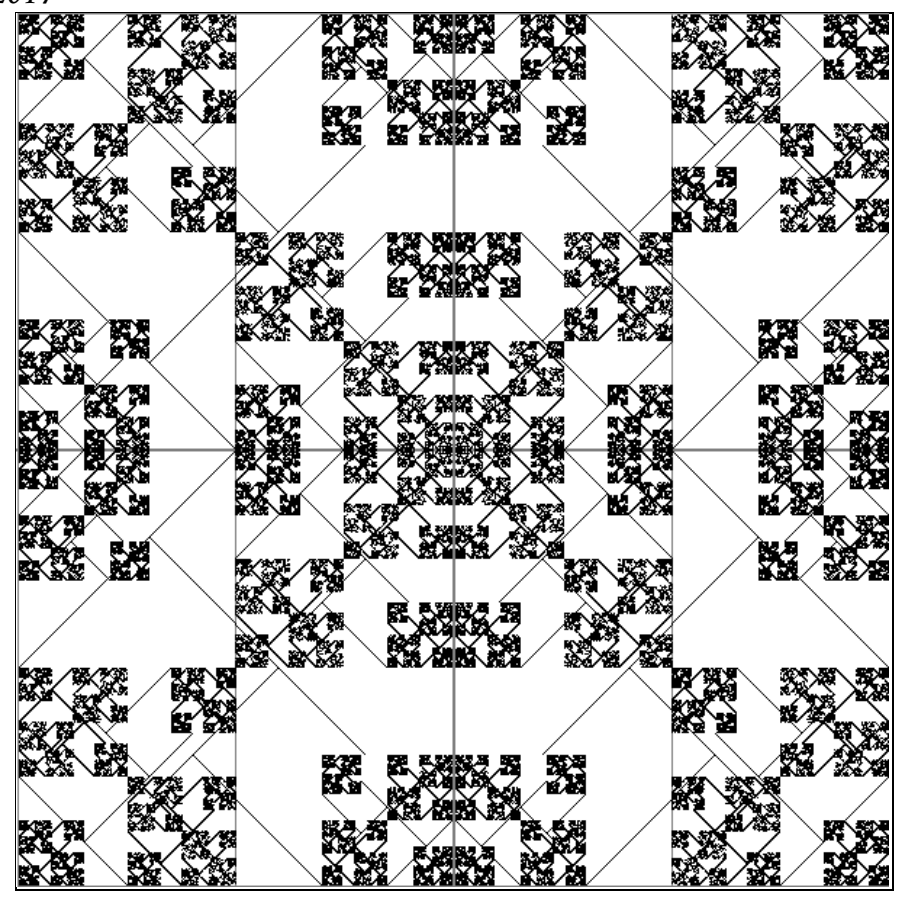

Gambar 15. Obyek fraktal hasil rancangan model-pengubinan fase satu

Pengubinan fase satu menghasilkan obyek fraktal motif batik yang simetris, karena merupakan komposisi hasil pencerminan secara horizontal, vertikal dan diagonal yang ditempatkan secara bersesuaian. Hasil pencerminan horizontal (gambar-13) ditempatkan pada pojok kanan atas, hasil pencerminan vertikal (gambar-12) ditempatkan pada pojok kiri bawah dan hasil pencerminan diagonal (gambar-14) ditempatkan pada pojok kanan bawah relatif terhadap obyek fraktal original (gambar-11) yang ditempatkan pada pojok kiri atas. Untuk dapat menghasilkan obyek fraktal motif batik yang lebih rapat diperlukan pengubinan fase berikutnya (fase dua dan seterusnya). Untuk pengubinan fase berikutnya cukup memanfaatkan duplikasi obyek fraktal pada fase sebelumnya dan ditempatkan pada keempat pojok seperti contoh pada gambar-15 untuk pengubinan fase dua.

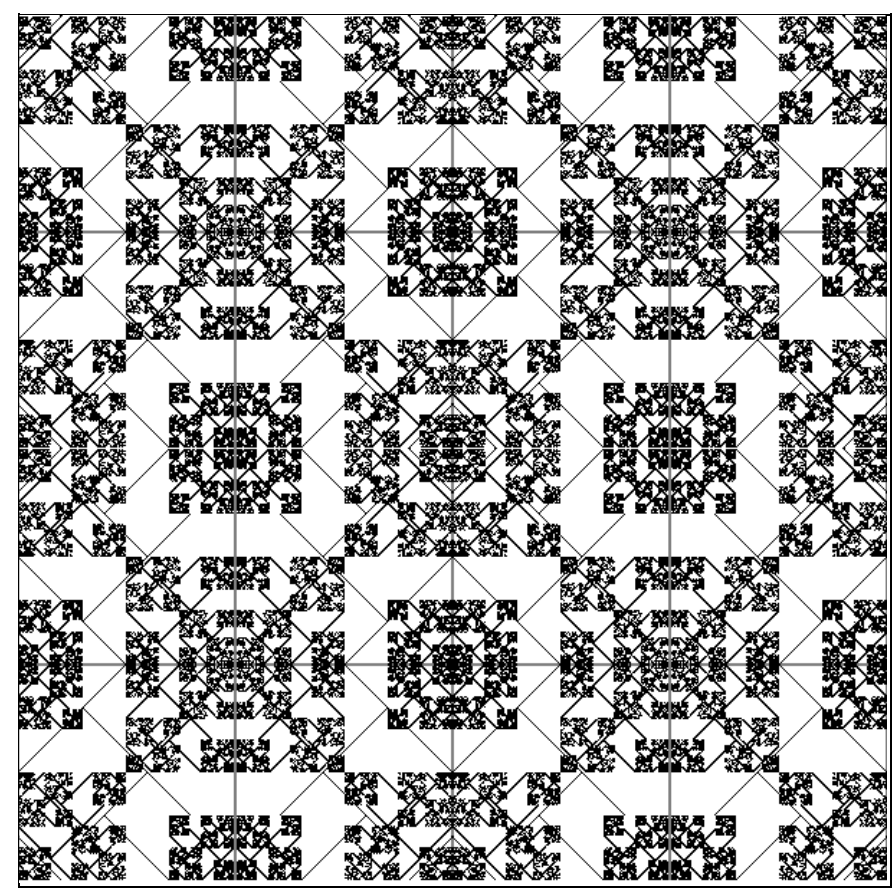

Gambar 16. Obyek fraktal hasil rancangan model-pengubinan fase dua 
Melalui proses perancangan ulang, rancangan motif batik sebelumnya dapat dimodifikasi sesuai kebutuhan berikutnya dengan mudah melalui proses Reverse engineering sehingga diperoleh rancangan baru. Sebagai ilustrasi hasil rancangan ulang pada gambar-17 ditampilkan model rancangan motif batik baru hasil modifikasi dari model rancangan motif sebelumnya yang ada pada gambar-5. Pada rancangan baru dilakukan pergeseran dua komponen garis, yaitu komponen ke-3 dan ke-4 dan pergeseran dua komponen yang memiliki sifat keserupaan diri yang berukuran kecil, yaitu komponen ke-7 dan ke-8, agar diperoleh ruang kosong dipojok kanan atas dan pojok kiri bawah.

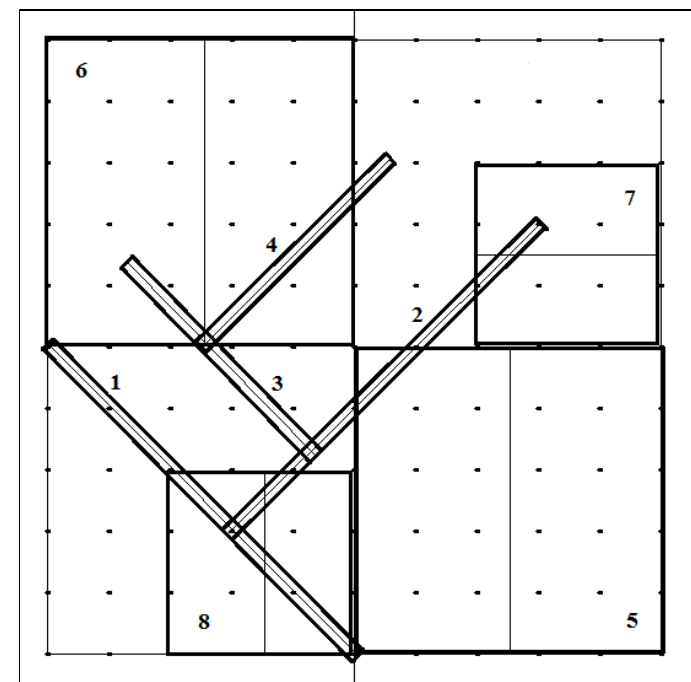

Gambar 17. Contoh model rancangan motif batik daur ulang dari gambar-5 (komponen-3, 4, 7 dan 8 gambar-5 digeser)

Obyek fraktal sebagai hasil rancangan setelah normalisasi ditampilkan pada gambar-18, dan kode IFS yang mewakilinya sebagai identitas obyek fraktal IFS ditampilkan pada tabel-3. Hasil pencerminan horizontal gambar18 ditampilkan pada gambar-19. Hasil pencerminan vertikal gambar-18 ditampil-kan pada gambar-20. Hasil pencerminan diagonal gambar-18 ditampilkan pada gambar-21. Hasil pengubinan keempat komponen hasil rancangan ditampilkan pada gambar-22.

TABEL 3. CONTOH KODE IFS GAMBAR-18 (SETELAH NORMALISASI)

\begin{tabular}{|c|c|c|c|c|c|c|}
\hline $\mathbf{a}$ & b & c & d & e & f & Prob \\
\hline \hline 0.0 & 0.5 & -0.0 & 0.5 & 0.0 & 0.0 & 0,0814 \\
\hline 0.0 & -0.5 & 0.0 & 0.5 & -0.2 & -0.2 & 0,0814 \\
\hline 0.0 & 0.3 & -0.0 & 0.3 & 0.1 & -0.5 & 0,0465 \\
\hline 0.0 & -0.3 & 0.0 & 0.3 & -0.1 & -0.7 & 0,0465 \\
\hline 0.5 & -0.0 & 0.0 & 0.5 & 0.25 & 0.0 & 0,2326 \\
\hline 0.5 & 0.0 & 0.0 & -0.5 & -0.25 & -1.0 & 0,2326 \\
\hline 0.0 & 0.35 & 0.25 & 0.0 & 0.5 & -0.625 & 0,1395 \\
\hline 0.3 & 0.0 & 0.0 & 0.3 & -0.15 & -0.0 & 0,1395 \\
\hline
\end{tabular}




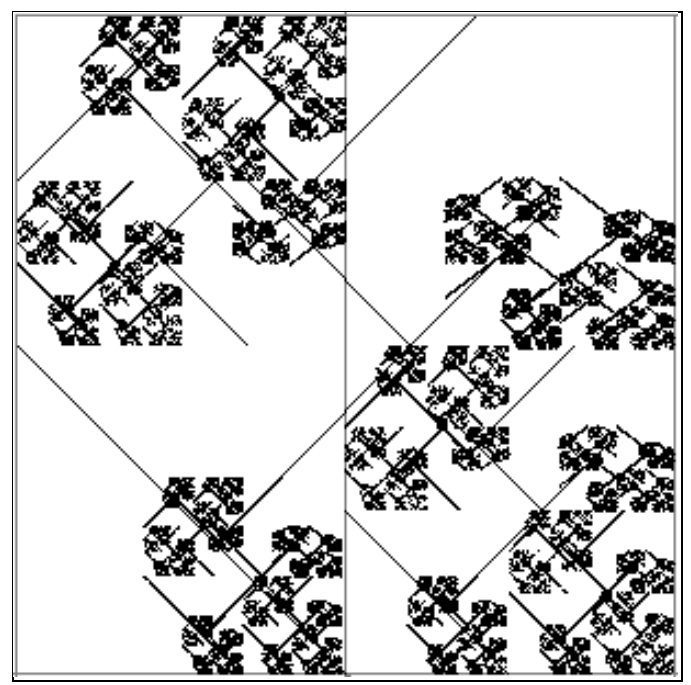

Gambar 18. Obyek fraktal hasil rancangan motif batik pada gambar-17

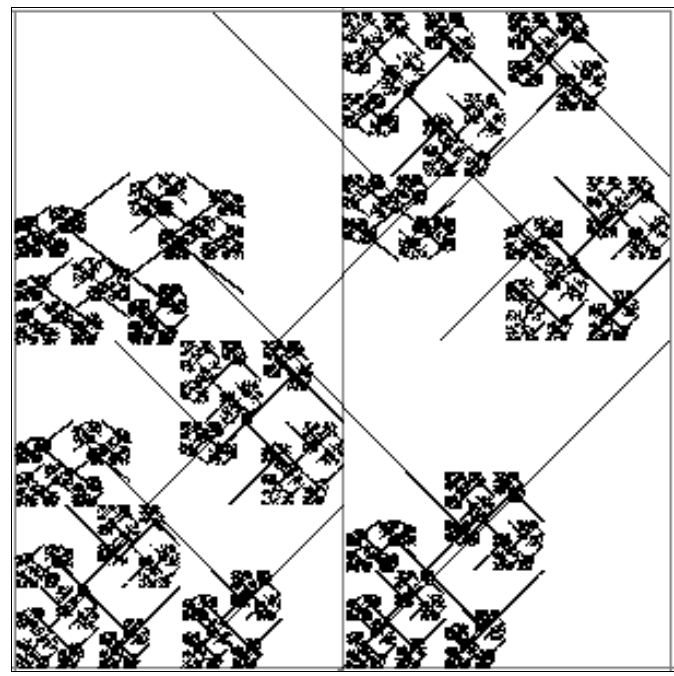

Gambar 19. Obyek fraktal hasil pencerminan horizontal gambar-18

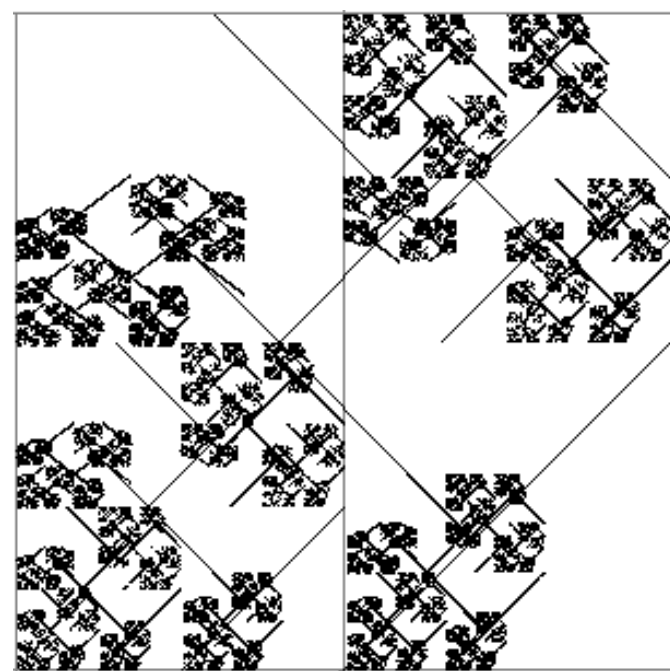

Gambar 20. Obyek fraktal hasil pencerminan vertikal gambar-18 


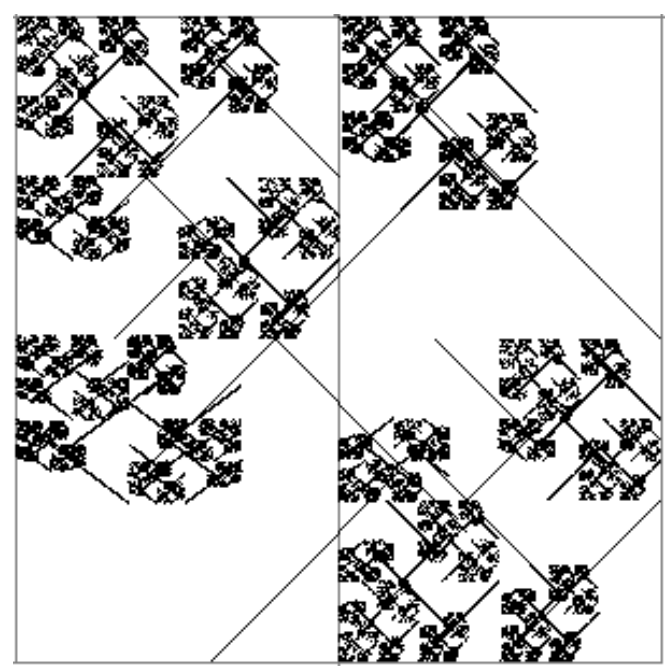

Gambar 21. Obyek fraktal hasil pencerminan diagonal gambar-18

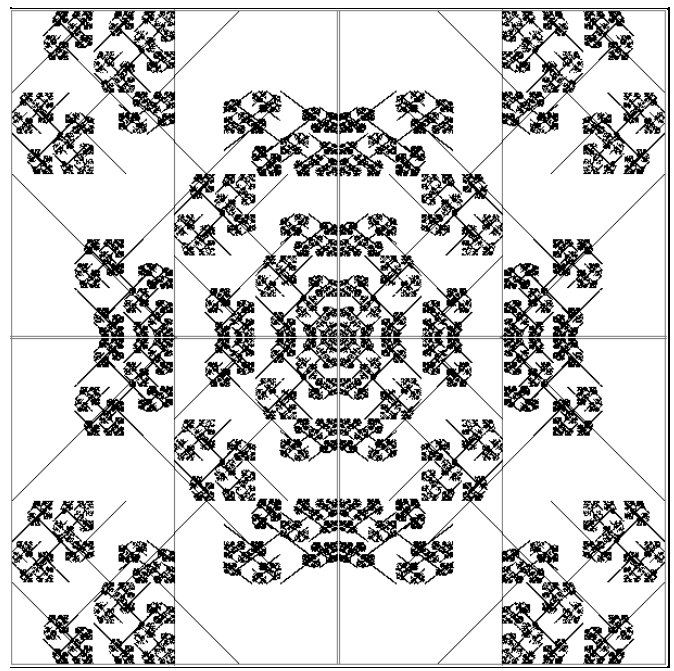

Gambar 22. Obyek fraktal hasil pengubinan gambar-18, 19, 20 dan 21 (fase satu)

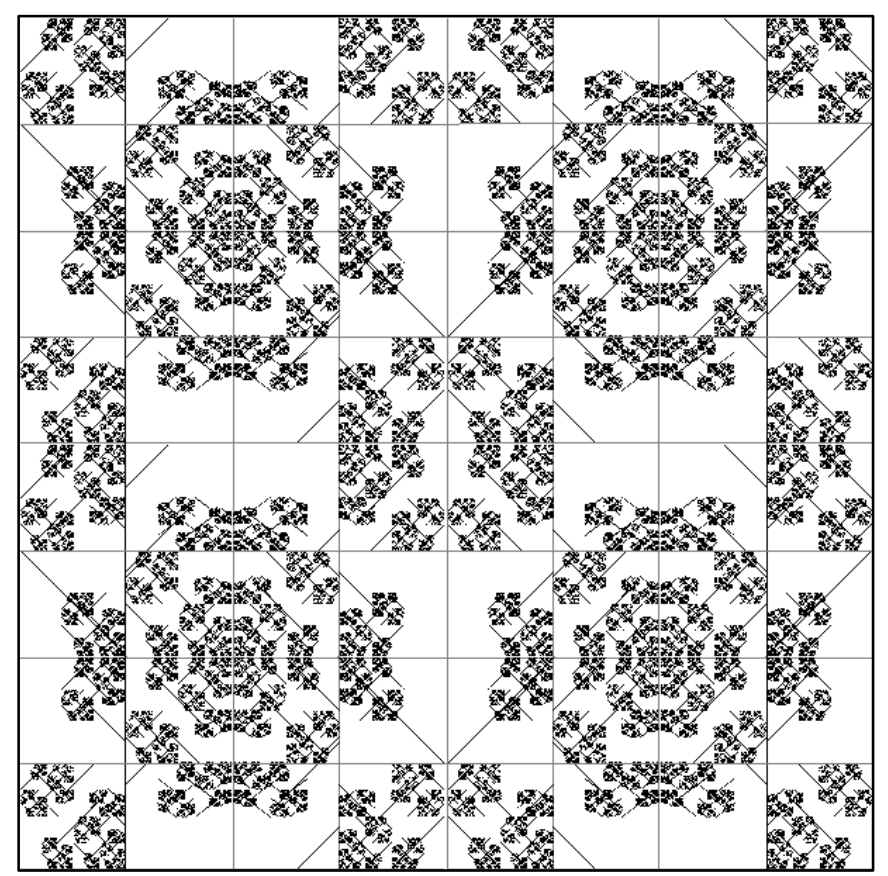


Hasil rancangan motif batik pengubinan fase dua dapat dilanjutkan ke fase tiga. Pada pengubinan fase tiga diperlukan empat obyek fraktal yang dihasilkan pengubinan fase dua yang ditempatkan pada keempat pojok kerangka motif batik yang lebih besar. Hasil rancangan motif batik pengubinan fase tiga tersebut ditampilkan pada gambar-24 dan gambar-25.

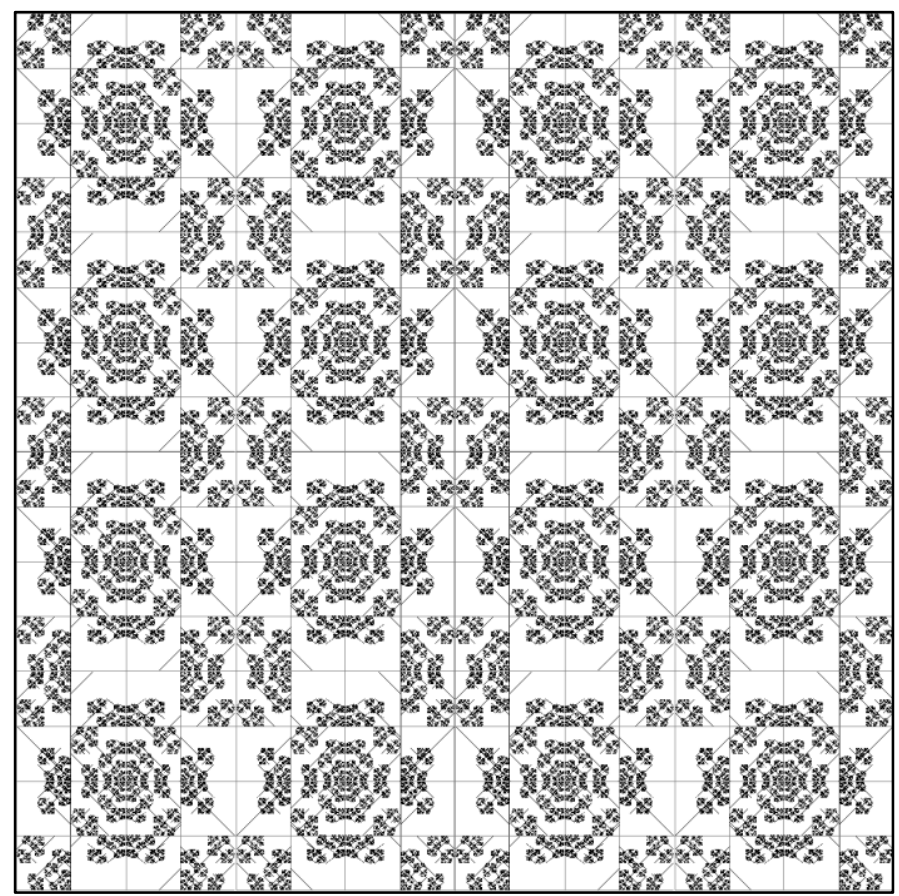

Gambar 24. Obyek fraktal motif batik hasil pengubinan empat gambar-23 (sebagai hasil pengubinan fase tiga versi daur ulang)

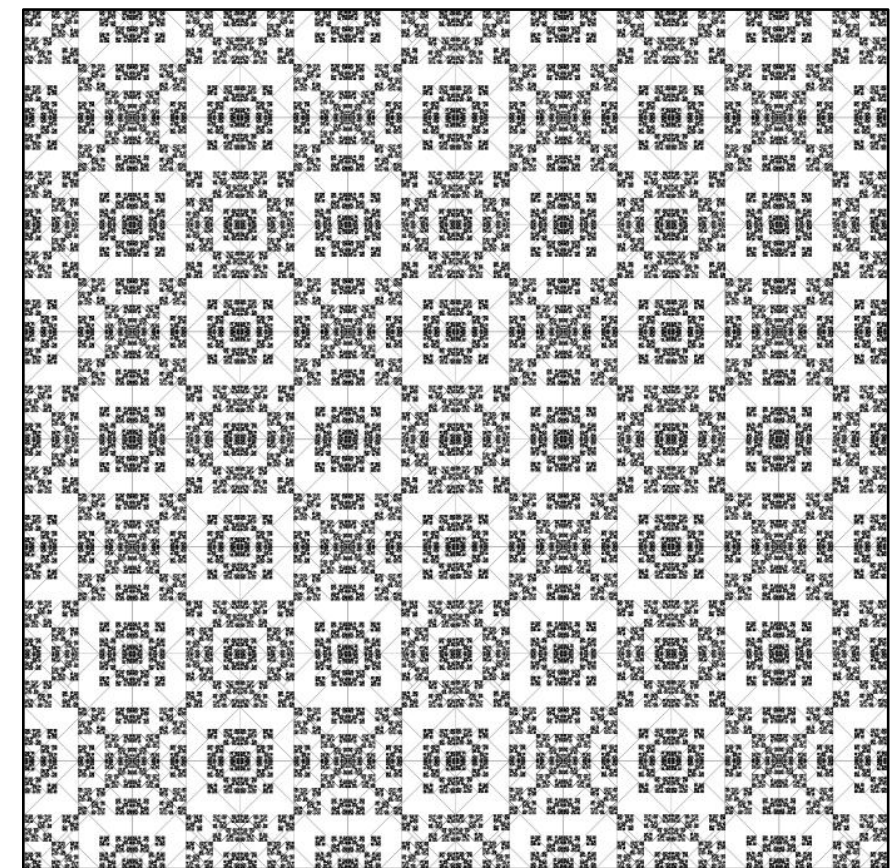

Gambar 25. Obyek fraktal motif batik hasil pengubinan empat gambar-16 (sebagai hasil pengubinan fase tiga versi original)

\section{KESIMPULAN}

Motif batik dapat dirancang melalui rancangan sebarang obyek fraktal IFS seperti obyek tanpa sifat keserupaan diri yang menghasilkan motif garis-garis sederhana. Motif batik yang menarik diperoleh dengan menambahkan 
komponen obyek fraktal yang mempunyai sifat keserupaan diri. Motif batik yang mempunyai ciri simetris dapat dibentuk melalui proses pencerminan dan pengubinan. Motif batik dapat juga dirancang ulang melalui proses Reverse engineering.

\section{DAFTAR PUSTAKA}

[1] Mandelbrot, Benoit B; "The Fractal Geometry of Nature"; WH Freeman and Company; 1982

[2] Barnsley, Michael F; Demko, S; "Iterated Function Systems and the Global Construction of Fractals"; Royal Society Publishing; 1985

[3] Hutchinson, John E; "Fractals Self-similarity”; Indiana University Mathematics Journal 30; 1981

[4] Barnsley, MF; "Fractals Everywhere"; Morgan Kaufmann, 2nd Edition; 1993

[5] Darmanto, T; "Animating Fractal of Things: Based on IFS Fractal Model”; Lambert Academic Publishing; @2016 Omniscriptum GmbH \& Co KG; ISBN 978-3-659-86851-1

[6] Darmanto, T; "Building Symmetrical Art Image by Multi-object of Fractal Model based on Mirroring Methods" ; prosiding SNIJA 2014; ISBN 978-602-70361-0-9 